do not use any specially significant figures, peculiar to each tribe, analogous to the totems of the North American Indians. They consider no kind of edible food unclean, but eat even monkeys, snakes, and scorpions, which they kill by means of a blow-pipe, throwing a dart poisoned with the juice of the Ipoh or Upas tree. For large game they use a kind of cross-bow, consisting of a sharpened bamboo spear placed horizontally on a grooved $\log$, and a bent sapling fastened back by a rattan cord. This cord is stretched across a path in the jungle, and, on being touched, releases the sapling with sufficient force to drive it completely through a deer's body. The Sakeis live in small huts built of bamboo and thatched with leaves of the Bertam palm, raised eight feet or more above the ground. They are shy and easily frightened, but are quite harmless, and are gradually becoming accustomed to Europeans, by whom they are employed to track game and to cut paths through the jungle. They are smaller in stature, but are otherwise very similar in appearance to the Malays, from whom they differ, however, in usually having wavy instead of straight-growing hair. . A few Malays are attached to every Sakei community to act as go-betweens in the sale of their produce, and the officials have received special instructions to protect these aboriginal tribes.

THE last issue (Bd. xxviii. Nos. 7 and 8 ) of the Vienna Geographical Society contains a paper by Dr. B. Jirus describing several visits made by him to the Scoglios, or small reefs off the Dalmatian coasts. - Dr. Polek writes on the colonies of Lipporwans, or Ras Kolniks, Russian schismatics who fled in the middle of the seventeenth century into Bessarabia and Moldavia, which they subsequently left for Bukowina in a romantic way. The writer discusses the history of their flight, and describes their manners and mode of life. The charm of mystery hangs around this small sect of the Greek Oriental Church.-Mr. H. Polakowsky discusses the historical value of the Spanish heroic poem "Araucana," recording the struggles the Spaniards for the possession of the central part of the present Republic of Chili. The object of the author of the paper is to draw attention to this poem, and its translation into German, and by a complete critical examination to separate the historical and actual from the poetical and imaginative.-Herr Baumann describes the projected geodetic work of Dr. Lenz's Congo expedition, and also writes from the vessel taking out the expedition on the present position of the question it is going out to solve.

THE Geographical Society of Hamburg has published a memorandum showing the territorial extent of the recent German annexations in the Pacific Ocean. Reduced to English measurements the German estimates are as follows:-Kaiser Wilhelm's Land (German New Guinea), 34,508 square miles ; New Ireland, 3,398.8 square miles; New Britain, 9,348.8 square miles; the Bismarck Archipelago, $15,261 \cdot 6$ square miles : in all about 65,512 English geographical square miles. The same authority estimates the area of New Guinea taken under British protection as $65,517.76$ square miles, or about the same as the total of the German annexations in the Pacific, and in each case the area acquired is rather more than twice that of Ireland.

THE Indépendance Belge announces that the two Portuguese explorers, Capt. Capello and Commander Ivens, who started last year upon an expedition across Africa, have reached the Cape after a most adventurous journey. Leaving Mossamedes in March, 1884, with an escort of 120 men recruited along the coast between that place and St. Paul de Loanda, they reached Quillimane, upon the eastern coast, to the south of Mozambique, in May, 1885, after having discovered the watershed whence the rivers of Central Africa flow north and east towards the sea. They travelled over 4500 miles of territory, and they are said to have discovered the sources of the Lualaba. They also came upon a region which is extraordinarily rich in copper, this being the district of Yaranganga, situated between the Lualaba and the Luapala. The chief of the country, however, was so hostile that they could not visit it in detail, but they think that as this was the first visit of white men his hostility may be appeased by judicious presents. Messrs. Capello and Ivens found that the tsetse fly was very abundant. The Indépendance Belge adds that the two explorers started again at the beginning of last month for Mossamedes, with the intention of returning to Europe by way of the Congo.

THE Calcutta correspondent of the Times states that the Government of India has conferred the title of Raj Bahadoor and a grant in perpetuity of a rent-free village in Oude on Pundit Kishen Singh Milwal, an employé of the Survey
Department, who is well known to all geographers for his explorations in Thibet, which have been published under the initials " A. K."

ON August 10 Col. Lockhart was at Hargil, near Gilghit, and is now probably marching to Chilval. His mission is expected to largely increase our knowledge of the country towards the upper waters of the Oxus.

\section{THE IRON AND STEEL INSTITUTE}

THE autumn meeting of the Iron and Steel Institute is being held in Glasgow this week, under the presidency of Dr. Percy, F.R.S.

On Tuesday, after the President had acknowledged the welcome given to the Institute by the Corporation of Glasgow and referred to the depression of trade, due, in his opinion, to over-production, and to be remedied only by a diminution of production or increased consumption, the three following papers were read, of which abstracts are given below.

On the Iron Trade of Scotland, by Mr. F. J. Rowan.The author separates the history of iron-making into two periods - the empirical, characterised by rude and imperfect appliances ; and the scientific, in which exact methods of working are employed, the introduction of the hot-blast in 1830 closing one and opening the other period. At this period there were in Scotland 27 blast-furnaces making 37,5000 tons; at present there are 92 in blast, with an average production of 200 tons per week each, and 269 puddling-furnaces at work, each producing annually 732 tons. There has been a steady increase in the production per furnace, and reduction in the amount of coal used to produce a ton of pig iron, the latter result being due to the introduction of closed tops, higher furnaces, and higher temperatures of blast. About two-thirds of the coal raised have been from the coal-measures, and one-third from the carboniferous limestone series. It is remarkable that the increased production of coal that has recently taken place has been accompanied by a reduction in the proportionate number of persons employed due to mechanical haulage and other improvements both below and above the surface. The increased manufacture of open-hearth steel, which employs a large quantity of Spanish and African ore, has caused a diminution in the output of ironstone, and has also had an influence on the pig-iron trade ; this, however. has been compensated for by the malleable iron tube manufacture, the manufacture of boiler tubes having increased ten times in the last twenty-five years. The author claims for Scotland a good record of advancement and improvement in connection with the iron trade--the first cylinderblowing engine, the first use of raw coal in the blast-furnace, the discovery of blackband ironstone by David Mushet, the invention of the hot blast by Neilson, and the collection and utilisation of the gases from the tunnel-head. The spirit of enterprise is still potent among Scottish ironmasters, and it is hoped more prosperous times will soon reward and further stimulate the energy and ability which are to be found in all branches of the iron trade in Scotland.

The Rise and Progress of the Scotch Steel Trade, by James Riley.-The author first makes a short reference to the manufacture of cast steel in crucibles, which is carried on only to a very small extent.

As regards the Bessemer process, the first trial, which proved unsuccessful, was made in 1857 , at the Coats Iron Works, by Mr. T. Jackson, the apparatus being fitted up from the drawings and letterpress in the Illustrated London News.

Other attempts on a small scale were afterwards made to introduce the manufacture, but since the application of the basic lining to the Bessemer converter, by which the pig-iron of the district will become available, the process has again received attention, and a large production is anticipated.

The history of the Scotch steel trade really commences with the formation, in $187 \mathrm{I}$, of the Steel Company of Scotland, which manufactured open-hearth steel by the processes of the late Sir William Siemens, their output being principally boiler and ship plates, angles, bars, castings, and forgings. The extension of manufacture in these directions has been dne to the fact that the Admiralty in 1875 declared for steel, "giving Siemens's steel a preference," and that in 1879 concessions were made to steel by Lloyds' and the Board of 'Trade, which has caused a great demand for shipbuilding and for the purposes of the civil engineer, who has recognised that by the use of steel, difficulties 
in constructive ènginecring can be overcome which would otherwise have been most formidable.

Mr. William Jones read a paper on processes for the recovery of tar and ammonia from blast-furnaces fed with raw coal. The coal generally employed is what is known as Scotch splint coal ; it contains on an average 40 per cent. of volatile matter and 50 to 55 per cent. of fixed carbon. The average amount of nitrogen in the coal is $\mathbf{I} \cdot 35$ per cent.; if all this nitrogen was evolved as ammonia and this again converted into sulphate, it would amount to $142 \frac{1}{2} \mathrm{lbs}$. of pure sulphate, equal to $152.8 \mathrm{lbs}$. of commercial sulphate containing 24 per cent. of real ammonia ; in blast-furnace practice only I 7 to 20 per cent. of the theoretical quantity, or 25 to $28 \mathrm{lbs}$. per ton, is recovered, whilst in gasworks I $4 \frac{1}{2}$ per cent. is evolved. Two methods are mainly employed : the one depending on the condensation or cooling of the gas from the blast-furnace, and the other on the treatment of the hot gas with either dilute sulphuric acid or sulphurous acid, which absorbs the ammonia in the gas; towers or scrubbers have to be used for washing the gas in both methods of treatment. The paper contains a detailed description of the various processes employed in carrying out these two methods for the recovery of by-products. The make of sulphate of ammonia from blast furnaces in Scotland bas been greatly exaggerated. Even a year hence, when the whole plant being laid down will be available, the make will not exceed 4000 tons per annum. If the gases of the whole of the blast-furnaces in Scotland at present in blast were being treated for ammonia, the turn-out of sulphate of ammonia would be some I8,ooo tons per annum, equal to about 22 per cent. of the present British production.

With the discussion of this paper proceedings on Wednesday began; after which Mr. J. Riley read a paper descriptive of an experimental cupola-furnace, which it is proposed to employ in connection with the open-hearth process, with the object of shortening the time employed. Many years ago Mr. IIackney tried at Landore the experiment of pre-melting the pig-iron in a cupola, whence the fluid charge was quickly and readily transferred to the melting-furnace. Instead, however, of saving three or four hours by charging fluid metal, it was found, on repeating the experiment at Hallside, that there was only a saving of about a quarter of an hour in time, obtained at the expense of the coke and labour expended at the cupola. This is due to the circumstance that during the melting of a charge in the open-hearth furnace a large proportion of the silicon and carbon is removed, leaving little more than half the carbon to be eliminated in subsequent operations. Now in the case of the fluid charges, which had been pre-melted with coke in the cupola, these changes have not taken place, and the time required to remove the impurities from the fluid metal, after being charged on the open-hearth furnace, is almost as long as that required to melt and purify the solid charge. The idea occurred to the author to substitute gaseous for solid fuel in the cupola. The gas generator has a closed grate and is dependent upon forced blast, and the air for supporting combustion in the body of the furnace is also obtained from the blower, and is heated.

The experiments made with this cupola prove that not only is there a saving in time and fuel, but that the percentage of silicon and carbon in the pig-iron and steel scraps are very much reduced, so that it is anticipated that when the fluid metal can be charged direct into the open-hearth furnace, the time for its conversion into mild steel will be greatly shortened.

This paper caused a very lively discussion, with which the proceedings on Wednesday terminated.

On Thursday amongst other papers was one descriptive of the Forth Bridge by Mr. Baker, which we print below in extenso.

In the afternoon of each day the members visited various steel and iron works in the neighbourhood.

\section{TIIE FORTH BRIDGE}

$A^{S}$ the members of the Iron and Steel Institute purpose paying by the Secretary to prepare a short paper on the subject for the information of the members, and do so with pleasure.

The North British Railway Company for many years have striven hard to obtain a physical connection of their lines north and south of the Forth by means of a bridge. Twenty years ago they were authorised by Act of Parliament to build a bridge across the Forth at a point five miles above the site of that now I Paper read at the Glasgow meeting of the Iron and Steel Institute by Mr. Benjamin Baker, M.Inst. C.E. under construction, but borings 120 feet in depth showed nothing but soft silt and mud, and the bridge, which was to have been two miles in length, inclusive of four spans of 500 feet each, was luckily abandoned, as the difficulties with the foundations would have proved practically insuperable. In 1873 another $\Lambda$ ct was passed for a bridge across a narrower and deeper part of the Forth at Queensferry. At low water the width of the channel there is about 4000 feet; and the island of Inchgarvie affording a foundation for a central pier, it was possible to cross the 200 feet deep portion of the sea-way by a couple of spans from I600 feet to 1700 feet each in the clear. Sir Thomas Bouch prepared a design for this bridge on the suspension principle, with towers 665 feet in height from base to summit, and the contract for its construction was let to $\mathrm{Mr}$. Arrol. Owing to the subsequent fall of the Tay Bridge, public confidence in Sir Thomas Bouch's design was shaken, and in session $188 \mathrm{I}$ a bill for the abandonment of the Forth Bridge was proceeded with. Whilst in Committee, the different companies interested, namely, the North British, Great Northern, North-Eastern, and Midland Railway Companies, ordered a final reference of the whole question to their respective consulting engineers, with the result that the abandonment bill was dropped, and the design for a cantilever or continuous girder bridge prepared by Mr. Fowler and myself, in consuliation with Mr. Harrison and Mr. Barlow, was substituted for the original suspension bridge. In 1882 the necessary Parliamentary powers were obtained, and in January 1883 the works were commenced by Messrs. Tancred, Arrol, and Co., the contractors.

The total length of viarluct included in the contract sum of $\mathbf{I}, 600,000 l$. is about $\mathbf{I} \frac{1}{2} \mathrm{miles}$, and there are-

$$
\begin{array}{rlrl}
2 & \text { spans of } & \text { r } 7 \text { ro feet each. } \\
2 & , & 675 & , \\
15 & , & 168 & , \\
5 & , & 25 & ,
\end{array}
$$

Including piers, there is thus one mile of main spans, and half a mile of viaduct approach. The clear headway is $\mathbf{r} 50$ feet above high water, and the tops of the great cantilevers are more than 200 feet higher still. There will be about 45,000 tons of steel in the superstructure of the bridge, and 120,000 cubic yards of masonry in the piers.

Piers. - The South Queensferry main pier consists of a group of four cylindrical piers of masonry and concrete, founded by means of pneumatic caissons on the strong boulder clay constituting the bed of the Forth at this point. Owing to the slope of the clay, the caissons required to be sunk to depths varying from about 70 feet to 90 feet below high water. The diameter ranges from 70 feet at the base to 60 feet at low-water level, above which the iron skin of the caisson is replaced by a facing of Aberdeen granite. At the base of the caissons is a working chamber 7 feet in height supplied with compressed air, and electrically lighted, for the men excavating the material. This chamber was kept clear of water by a pressure of air considerably less, as a rule, than that due to the head of water outside. For example, at 90 feet below high water, when the north-east caisson had been sunk through a considerable thickness of silt, the air-pressure required to be maintained at $181 \mathrm{bs}$. per square inch only, although at the reduced depth of 57 feet it was found convenient to work at $30 \mathrm{lbs}$. air-pressure. Three shafts and air-locks were provided for each /caisson, two for the excavated material, and one for the men. The former had two horizontal sliding doors actuated by small hydraulic rams, and the skip containing the clay and boulders was hoisted up the 90 -feet shaft by a steam-engine mounted on the side of the air-lock. As a rule, from 200 to 300 skips of excavated material were raised per day of 24 hours by a force of from 20 to 30 men. The maximum number of skip-loads was 363 , and of men 33 . The size of the skips was 3 feet diameter by 4 feet 3 inches high. Owing to the extreme hardness of the clay it was necessary to provide a certain number of spades having hydraulic rams in the handles, which, abutting against the roof of the working chamber, sliced the clay readily.

$\Lambda$ the prosent time three of the South Queensferry caissons have been sunk successfully to the full depth, and the fourth and last would also have been completed but for an unfortunate accident which happened to it at the beginning of the ycar. By some means the caisson, which had been floated into position for some weeks, accidentally filled with water, and sank and slid forward on the mud. It is now being carefully cased in timber to admit of the water being pumped out and the caisson floated again into position. 